\title{
Effect of Elevated Temperatures on Properties of Blended Cements with Clinoptilolite
}

\section{Ahmet BEYCIOGLU ${ }^{1}$ *, Hüseyin Yılmaz ARUNTAŞ ${ }^{2}$, Osman GENCEL ${ }^{3}$, Haley E. HAGG LOBLAND ${ }^{4}$, Ayhan ŞAMANDAR ${ }^{5}$, Witold BROSTOW ${ }^{4}$}

\author{
${ }^{1}$ Department of Civil Engineering, Technology Faculty, Düzce University, Düzce, Turkey \\ ${ }^{2}$ Department of Civil Engineering, Technology Faculty, Gazi University, Beşevler, 06500 Ankara, Turkey \\ ${ }^{3}$ Department of Civil Engineering, Faculty of Engineering, Bartin University, Bartin 74100, Turkey \\ ${ }^{4}$ Laboratory of Advanced Polymers and Optimized Materials (LAPOM), Department of Materials Science and \\ Engineering and Department of Physics, University of North Texas, 3940 North Elm Street, Denton, TX 76207, USA \\ ${ }^{5}$ Department of Construction, Vocational School, Düzce University, Düzce, Turkey
}

cross $^{\text {ref }}$ http://dx.doi.org/10.5755/j01.ms.22.4.13354

\section{Received 07 October 2015; accepted 03 June 2016}

\begin{abstract}
We have investigated the effect of elevated temperature on properties of clinoptilolite blended cements. Clinoptilolite was used at $5 \%, 10 \%, 15 \%$ and $20 \%$ replacement by weight for Portland cement while sand and water quantities were kept constant in all mix designs. Dry weights, flexural strengths, and compressive strengths of specimens were determined as a function of time. The same properties were again evaluated after specimens, having reached the age of 90 days, were exposed to $300{ }^{\circ} \mathrm{C}, 400{ }^{\circ} \mathrm{C}$ and $500{ }^{\circ} \mathrm{C}$ temperatures for $3 \mathrm{~h}$. Initial setting times for all cements prepared were $\geq 60$ minutes, the limiting time according to TS EN 197-1. The mortars with $5 \%$ or $10 \%$ cliniptilolite substitution have compressive strength exceeding $42.5 \mathrm{MPa}$ after being subjected to $400{ }^{\circ} \mathrm{C}$ and $500{ }^{\circ} \mathrm{C}$.

Keywords: blended cement, clinoptilolite, cement compressive strength, elevated temperatures.
\end{abstract}

\section{INTRODUCTION}

Owing to its good performance to cost ratio, concrete is one of the most widely used traditional materials in construction $[1-6]$. Concrete is a heterogeneous material consisting of cement, water, sand and aggregates [7]. The properties of concrete are strongly dependent on the cement used [8]. While cement production originally focused on Portland cement, subsequent methods of production have replaced parts of the clinker content with supplementary cementitious materials. As a consequence, fly ash from coal power plants, granulated slag from iron production, and natural pozzolans are being used in increasing amounts [9]. The term pozzolan is associated with all siliceous/aluminous materials, which, in finely divided form and in presence of water, react chemically with $\mathrm{Ca}(\mathrm{OH})_{2}$ in order to form compounds that possess cementitious properties [10].

Cement replacements include also volcanic ash, pumice, rice husk ash, silica fumes, and more [11]. It is well known that the incorporation of pozzolans into cement or concrete systems provides many benefits to properties of both fresh and hardened concrete such as improvement in workability, reduction in the heat of hydration, low permeability, high ultimate strength, and control of alkali-silica expansion. However, most pozzolanic materials, especially natural pozzolans, tend to increase the mixing water requirement for concrete and lower the rate of strength development. Therefore, for

\footnotetext{
* Corresponding author. Tel.: +90-380-5421133; fax: +90-380-5421134 E-mail address: abeycioglu@duzce.edu.tr (A. Beycioglu)
}

structural applications their proportion in blended Portland cements is generally limited to $30 \%$ or less [12]. Zeolitic tuffs have been widely used, as mixtures with lime, in construction since Roman times. There is much discussion on the pozzolanic activity of natural zeolites and their incorporation in blended cements [13]. Most cement plants consume much energy and produce a large amount of undesirable products which affect the environment. In order to reduce energy consumption and $\mathrm{CO}_{2}$ emission and also to increase production, cement manufacturers are blending or intergrinding mineral additions such as slag, natural pozzolan, sand and limestone [14]. Natural, zeoliterich volcanic tuffs have been proposed and frequently are used as pozzolans in several countries such as Bulgaria, China, Cuba, Germany, Greece, Italy, Jordania, Russia, Turkey and United States [15].

Natural zeolite contains large quantities of reactive $\mathrm{SiO}_{2}$ and $\mathrm{Al}_{2} \mathrm{O}_{3}$. Similar to other pozzolanic materials such as silica fume and fly ash, zeolite substitution can improve the strength of concrete by the pozzolanic reaction with $\mathrm{Ca}(\mathrm{OH})_{2}$, an effect that is reportedly generally greater in concrete than in cement alone [16]. Zeolite tuff + lime mixtures have been also used in construction since ancient times. Today, more than 50 natural and 150 synthetic zeolite minerals are in use. In China the total quantity of zeolite consumed is as much as 30 million tons per year [17]. Concrete is more durable against elevated temperature and fire effects than many other construction materials [18]. Although ordinary concrete is considered to have a satisfactory fire resistance [19], it can lose $40-60 \%$ of its original strength upon exposure to $500{ }^{\circ} \mathrm{C}$ [20]. 
Concrete surfaces exposed to heat are significantly affected [21]. The most important effects of elevated temperatures on concrete are: dehydration of cement paste, porosity increase, modification in moisture content, thermal expansion, alteration of pore pressure, strength loss, thermal cracking due to incompatibility, thermal creep, and thermal spalling due to excessive pore pressure [22].

We have studied the effects of elevated temperatures on physico-mechanical properties of blended cements containing clinoptilolite. Clinoptilolite is a natural zeolite comprised of a microporous arrangement of silica and alumina tetrahedra. It has the complex formula: $(\mathrm{Na}, \mathrm{K}, \mathrm{Ca})_{2-3} \mathrm{Al}_{3}(\mathrm{Al}, \mathrm{Si})_{2} \mathrm{Si}_{13} \mathrm{O} .12 \mathrm{H}_{2} \mathrm{O}$. It forms white to reddish tabular monoclinic tectosilicate crystals with a Mohs hardness of 3.5 to 4 and a specific gravity of 2.1 to 2.2 .

\section{MATERIALS AND METHODS}

The materials used for this study consisted of clinoptilolite and ordinary Portland cement (OPC) CEM I 42.5 R. Natural zeolite in clinoptilolite form used in this study was obtained from the Gördes Mining Company, Gordes region, Turkey. The chemical, physical and mechanical properties of Portland cement and clinoptilolite used in the study are given in Table 1. Clinoptilolite is characterized as a natural pozzolan according to the Turkish standard TS EN 197-1. This standard specifies that the reactive $\mathrm{SiO}_{2}$ content shall be not less than $25 \%$ by mass; clinoptilolite samples used in this research satisfy this requirement, as seen in Table 1. The Portland cement (CEM-I $42.5 \mathrm{R}$ ) used in the experimental study was obtained from OYAK Bolu Cement and conforms to TS EN 197-1.

Mineralogical and microscopic analysis of clinoptilolite were provided by the manufacturer, Gördes Mining Company. As seen in an XRD pattern in Fig. 1, the zeolite used by us consists of a high concentration of the clinoptilolite phase with very low quartz and opal cristobalite (opal CT) content. The crystal structure of the clinoptilolite is presented as a scanning electron micrograph in Fig. 2.

The mortar mixtures were prepared with $450 \mathrm{~g}$ of cement, $1350 \mathrm{~g}$ of CEN standard sand, and $225 \mathrm{~mL}$ of water and mixed in accordance with TS EN 196-1. Clinoptilolite was used at $0 \%, 5 \%, 10 \%, 15 \%$ and $20 \%$ replacement by weight for cement - while sand and water quantities were kept constant. Water demand and setting time analysis of mortars were performed with an automatic Vicat machine while soundness tests were carried out using a Le Chatelier tool. These measurements were conducted according to TS EN 196-3. For the mixture preparation, the mortars were placed in $40 \times 40 \times 160 \mathrm{~mm}$ prismatic molds. After removal from the molds at $24 \mathrm{~h}$ of age, mortar specimens were immersed in water saturated with lime at $20^{\circ} \mathrm{C}$ until the time of testing. Compression and three points bending tests were conducted at 7,28 and 90 days of age. The results reported are the averages for three flexural specimens and six compression tests. The elevated temperature resistance tests of the mortars were conducted on specimens aged to 90 days. At that time, dry weights, flexural strengths and compressive strengths were determined. Then each specimen type was exposed to $300{ }^{\circ} \mathrm{C}, 400{ }^{\circ} \mathrm{C}$, and $500{ }^{\circ} \mathrm{C}$ temperatures for $3 \mathrm{~h}$ in a furnace. After the 3-hour-exposures at the specified temperatures, the hot mortar specimens were cooled in laboratory conditions. Upon reaching room temperature, the dry weights and flexural strengths were determined, taking the averages of three test results while the compressive strengths were determined by taking the average of six test results.

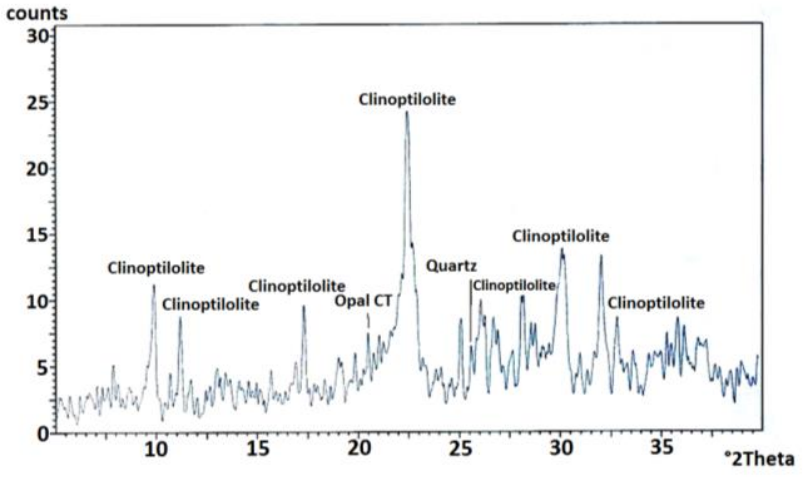

Fig. 1. XRD analysis of zeolite

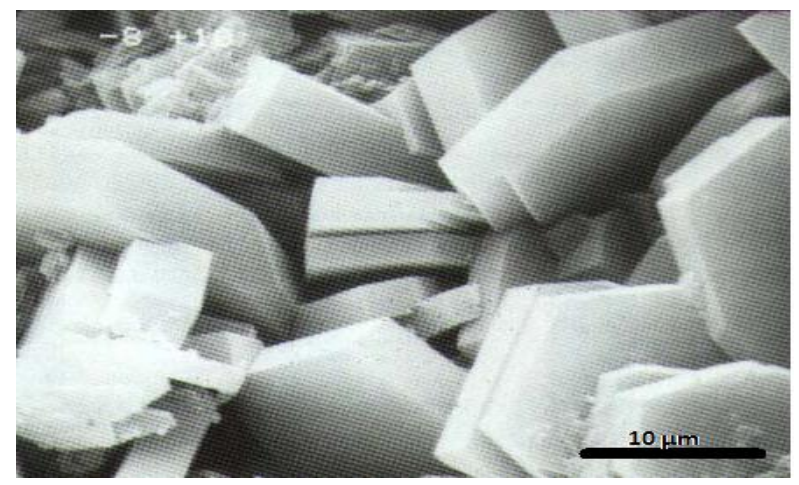

Fig. 2. SEM view of zeolite

\section{PHYSICAL PROPERTIES}

The physical properties of the reference Portland cement (RF) and Portland cement blended with clinoptilolite (CL5, CL10, CL15, CL20) are given in Table 2. As seen in that Table, the water content of mortars increased from $29.8 \%$ to $36.8 \%$ with increasing clinoptilolite concentration in the cement. Simultaneously the specific gravity decreases with increasing clinoptilolite concentration, owing to the porous structure of clinoptilolite. Actually, a reduction of specific gravity can be useful for the reduction of the dead weight of the structure. Volume expansion values of all specimens are acceptable within the limit of $\leq 10 \mathrm{~mm}$ given by TS EN 197-1. The initial and final setting times of mortars are listed in Fig. 3. Compared to the reference cement (RF), the initial setting time was lowered from $140 \mathrm{~min}$ to $130 \mathrm{~min}$ by the addition of $5 \%$ clinoptilolite.

Further addition of clinoptilolite lengthened the initial setting time up to $230 \mathrm{~min}$. Similarly, the final setting time of clinoptilolite cements was shorter for $5 \%$ substitution and longer for specimens with higher concentration of clinoptilolite. Clearly all values of initial setting time are above the standard lower limit requiring a time $\geq 60 \mathrm{~min}$. 
Table 1. Physical, chemical and mechanical properties of cement and clinoptilolite used

\begin{tabular}{|c|c|c|c|c|}
\hline Chemical composition, $\%$ & Cement & Clinoptilolite & Physical Properties of cement & \\
\hline $\mathrm{SiO}_{2}$ & 18.9 & 67.1 & Initial setting time, $\min$ & 140 \\
\hline $\mathrm{Al}_{2} \mathrm{O}_{3}$ & 5.3 & 11.8 & Final setting time, $\min$ & 160 \\
\hline $\mathrm{Fe}_{2} \mathrm{O}_{3}$ & 4.1 & 1.5 & Volume expansion, $\mathrm{mm}$ & 1 \\
\hline $\mathrm{CaO}$ & 64.7 & 2.2 & Specific gravity & 3.18 \\
\hline $\mathrm{MgO}$ & 1.3 & 1.2 & Specific surface (Blaine, $\mathrm{cm}^{2} / \mathrm{g}$ ) & 4663 \\
\hline $\mathrm{SO}_{3}$ & 2.9 & - & \multirow{2}{*}{\multicolumn{2}{|c|}{ Mechanical properties of cement }} \\
\hline $\mathrm{Na}_{2} \mathrm{O}$ & 0.2 & 0.4 & & \\
\hline $\mathrm{K}_{2} \mathrm{O}$ & 0.5 & 3.4 & \multicolumn{2}{|l|}{ Compressive strength, $\mathrm{MPa}$} \\
\hline Loss of ignition & 3.8 & 12.5 & 7 days & 45 \\
\hline Insoluble residue & 0.6 & & 28 days & 55 \\
\hline Free $\mathrm{CaO}$ & 1.52 & & 90 days & 62 \\
\hline
\end{tabular}

Table 2. Physical properties of the blended cement mortars

\begin{tabular}{|l|c|c|c|c|c|}
\hline & RF & CL5 & CL10 & CL15 & CL20 \\
\cline { 2 - 6 } Water demand, $\%$ & 29.8 & 30.8 & 32.8 & 34.8 & 36.8 \\
\hline Specific gravity, $\mathrm{g} / \mathrm{cm}^{3}$ & 3.18 & 3.09 & 3.02 & 2.92 & 2.86 \\
\hline Volume expansion, $\mathrm{mm}$ & 1 & 1 & 1 & 1 & 1 \\
\hline
\end{tabular}

Furthermore, it is seen from Fig. 3 that clinoptilolite substitution is obviously a factor in determining the setting times of cement mortars.

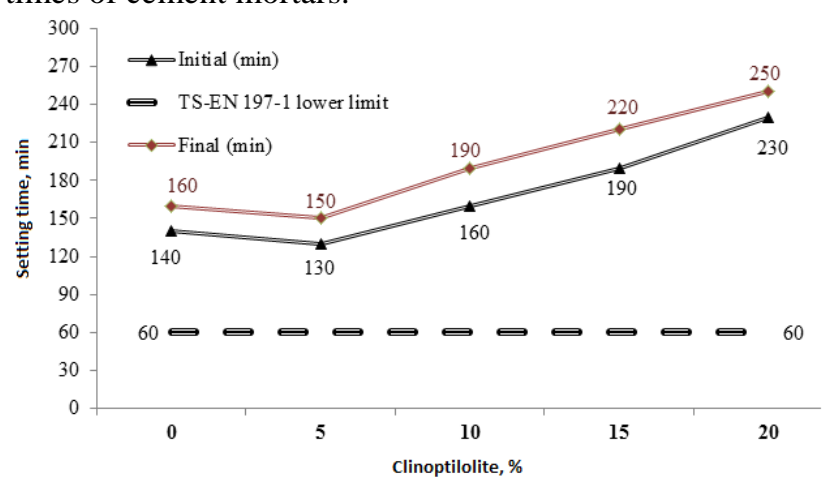

Fig. 3. Setting time variations for cements

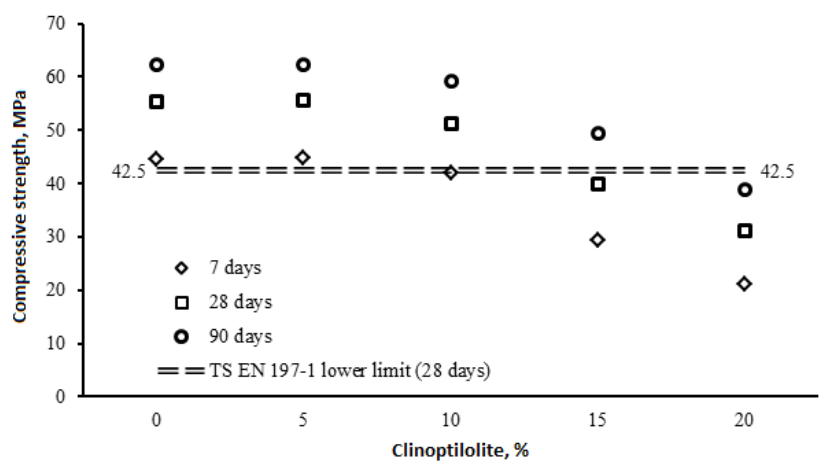

Fig. 4. Compressive strengths values for cements

\section{MECHANICAL PROPERTIES}

The compressive strengths of the mortars were determined at 7, 28 and 90 days, with the results shown in Fig. 4. As expected, the compressive strength values increase with age. Compared to the compressive strength of the plain cement reference, that of the specimen with $5 \%$ clinoptilolite substitution was essentially unchanged.

The specimen with $10 \%$ clinoptilolite had slightly lower values but still suitable given the minimum value of
42.5 MPa for the appropriate Turkish Standard. Further substitution up to $15 \%$, and $20 \%$ reduces the compressive strength even to values below the lower limit of acceptability (according to the standard TS EN 197-1).

The flexural strength of concrete or mortar is important for pavements. There is no lower limit value for the flexural strength in EN 197-1. The behavior of both RF and clinoptilolite blended cements under flexural force - as seen in Fig. 5-are similar to their behavior under compression.

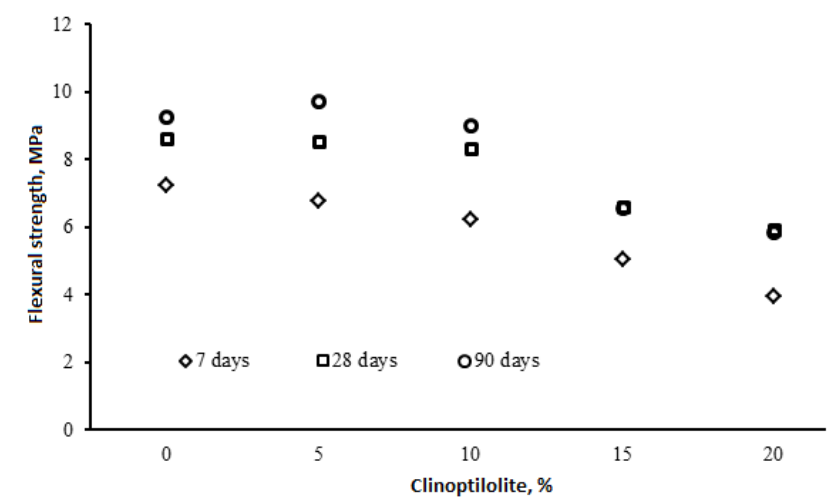

Fig. 5. Flexural strength results for the cements

\section{WEIGHT LOSSES, COMPRESSIVE STRENGTHS AND FLEXURAL STRENGTHS OF CLINOPTILOLITE BLENDED CEMENTS AFTER HIGH TEMPERATURE EXPOSURE}

Table 3 lists the weight loss of the mortars resulting from exposure to elevated temperatures $\left(100{ }^{\circ} \mathrm{C}\right.$ ovendried, 300, 400 and $500{ }^{\circ} \mathrm{C}$ ), each time for 3 hours. As mentioned in the Methods, all data is taken at the age of 90 days. The unit weights decrease with increasing temperature. Compressive strength test results of blended cements after high temperature conditions are presented in Fig. 6. 
Table 3. Dry weights of specimens

\begin{tabular}{|c|c|c|c|c|c|c|c|}
\hline & Oven-dried & \multicolumn{2}{|c|}{$300{ }^{\circ} \mathrm{C}$} & \multicolumn{2}{|c|}{$40{ }^{\circ} \mathrm{C}$} & \multicolumn{2}{c|}{$500^{\circ} \mathrm{C}$} \\
\cline { 2 - 9 } & Weight & Weight & Weight loss, $\%$ & Weight & Weight loss, \% & Weight & Weight loss, $\%$ \\
\hline RF & 546 & 522 & 4.53 & 518 & 5.22 & 514 & 5.95 \\
\hline CL5 & 543 & 519 & 4.35 & 516 & 5.00 & 510 & 6.06 \\
\hline CL10 & 539 & 519 & 3.72 & 515 & 4.56 & 508 & 5.89 \\
\hline CL15 & 523 & 501 & 4.38 & 504 & 3.77 & 482 & 7.93 \\
\hline CL20 & 505 & 487 & 3.53 & 484 & 4.03 & 481 & 4.76 \\
\hline
\end{tabular}

For every specimen type, the compressive strength decreases as the temperature of exposure increases. The values after exposure to the highest temperature, $500{ }^{\circ} \mathrm{C}$, are slightly lower than the values for the same specimen at the age of 7 days. The trend in values as a function of clinoptilolite content is the same for high-temperature exposed specimens as for the specimens dried at $100{ }^{\circ} \mathrm{C}$.

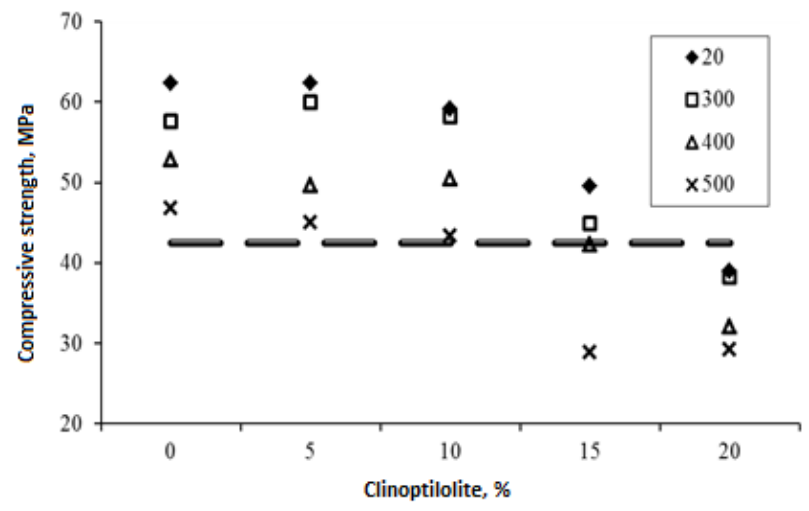

Fig. 6. Compressive strength of mortars subjected to elevated temperatures

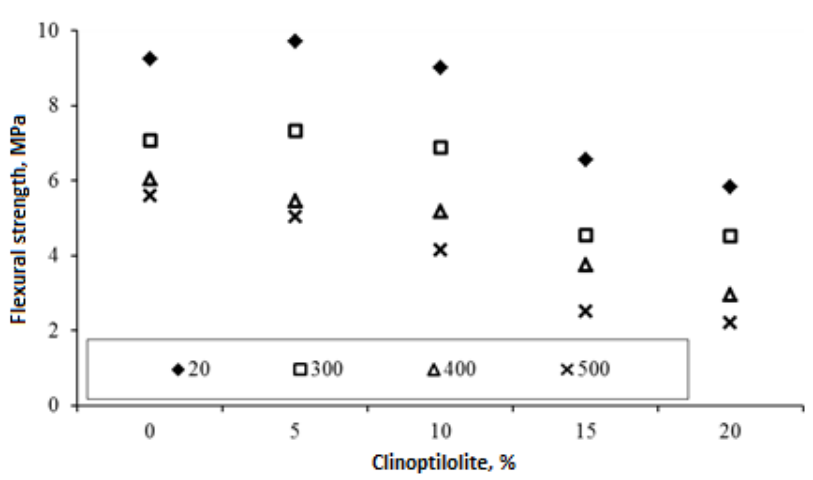

Fig. 7. Flexural strength results for blended cement mortars after high temperatures

There are only slight differences between properties of the reference cement and of cements substituted with $5 \%$ or $10 \%$ clinoptilolite. The further substitution of $15 \%$ or $20 \%$ substantially lowers the compressive strength for all temperatures. In reference to the standard lower limit, all specimens except CL20 are suitable for use after exposure to $300{ }^{\circ} \mathrm{C}$ while CL5 and CL10 perform above the limit even after exposure to $500{ }^{\circ} \mathrm{C}$. Relative changes of compressive strengths of blended cements subjected to different temperatures are presented in Fig. 7. As seen from that figure, all mortars have a residual strength over $60 \%$ which is important in terms of structural performance.
Flexural strengths of blended cement mortars are presented in Fig. 7. Knowledge of flexural strength is important in applications such as the design of highways, airfield slabs, and dams. The behavior of both RF and clinoptilolite blended cements under flexural force application are similar to their behavior under compressive forces. As expected, flexural strength decreases with exposure to increasingly higher temperatures, while the effect of clinoptilolite substitution is the same as before.

\section{CONCLUSIONS}

We have demonstrated the feasibility of using clinoptilolite as a substitute for cement to produce mortars that meet the requirements of existing standards. There is some increase in water demand with clinoptilolite substitution, but setting times exceed the standard lower limit.

Cements with higher levels of clinoptilolite substitution do not perform as well, especially after high temperature exposure, but up to $15 \%$ substitution can provide suitable properties after 90 days aging and after exposure to $300{ }^{\circ} \mathrm{C}$.

However, the substitution of cement with $5 \%$ or $10 \%$ clinoptilitolite yields specimens with properties nearly identical to those of unsubstituted concrete.

Moreover, at these levels of substitution, specimens perform well even after 3 hours exposure at temperatures up to $500{ }^{\circ} \mathrm{C}$. Therefore, it is clearly possible to produce clinoptilolite substituted cement up to $10 \%$ with adequate compressive strength after 90 days curing.

\section{Acknowledgments}

The Authors thank to Dr. Serpil Özaydin (R\&D Director of Gördes Mining Inc.) and Selim Topbas (Chemical Engineer at Oyak Cement Group) for providing materials.

\section{REFERENCES}

1. Mindess, S. Concrete Materials Journal of Materials Education 5 1982: pp. 983-1046

2. Regoud, M. New Progress in Inorganic Building Materials Journal of Materials Education 9 1986: pp. 201-228

3. Roy, D.M., Scheetz, B.E., Silsbee, M.R. Processing of Optimized Cements and Concretes Via Particle Packing MRS Bulletin 18 1993: pp. 45-49.

4. Mcphee, D.E., Glasser, F.P. Immobilization Science of Cement Systems 18 MRS Bulletin 1993: pp. 66-71. http://dx.doi.org/10.1557/S0883769400043931

5. Martinez-Barrera, G., Vigueras-Santiago, E., Gencel, O., Hagg Lobland, H.E. Polymer Concretes: A Description and 
Methods for Modification and Improvement Journal of Materials Education 33 2011: pp. 37-52.

6. Nagrockienė, D., Gailius, A., Skripkiūnas, G., Pundienè, I., Girskas, G., Abasova, A. The Effect of Plasticizing Admixture on the Physical and Mechanical Properties of Concrete with Limestone Cement Materials Science (Medziagotyra) 19 2013: pp. 337-342.

7. Gencel, O., Ozel, C., Koksal, F., Martinez-Barrera, G., Brostow, W., Polat, H. Fuzzy Logic Model for Prediction of Self-Compacting Concrete Properties Materials Science (Medziagotyra) 19 2013: pp. 203-215.

8. Karakurt, C., Topcu, İ.B. Effect of Blended Cements Produced with Natural Zeolite and Industrial By-Products on Alkali-Silica Reaction and Sulfate Resistance of Concrete Construction and Building Materials 25 2011: pp. 1789-1795.

9. Schneider, M., Romer, M., Tschudin, M., Bolio, H. Sustainable Cement Production-Present and Future Cement and Concrete Research 41 2011: pp. 642-650.

10. Perraki, T., Kontori, E., Tsivilis, S., Kakali, G. The Effect of Zeolite on the Properties and Hydration of Blended Cements Cement \& Concrete Composites 32 2010: pp. $128-133$.

11. Khandaker, M., Hossain, A. Pumice Based Blended Cement Concretes Exposed to Marine Environment: Effects of Mix Composition and Curing Conditions Cement \& Concrete Composites 30 2008: pp. 97-105.

12. Uzal, B., Turanli, L. Studies on Blended Cements Containing a High Volume of Natural Pozzolans Cement and Concrete Research 33 2003: pp. 1777-1781.

13. Perraki, T., Kakali, G., Kontoleon, F. The Effect of Natural Zeolites on the Early Hydration of Portland Cement Microporous and Mesoporous Materials 61 2003: pp. $205-212$.
14. Ghrici, M., Kenai, S., Said-Mansour, M. Mechanical Properties and Durability of Mortar and Concrete Containing Natural Pozzolan and Limestone Blended Cements Cement \& Concrete Composites 29 2007: pp. 542-549.

15. Caputo, D., Liguori, B., Colella, C. Some Advances in Understanding the Pozzolanic Activity of Zeolites: The Effect of Zeolite Structure Cement \& Concrete Composites 30 2008: pp. $455-462$. http://dx.doi.org/10.1016/j.cemconcomp.2007.08.004

16. Canpolat, F., Yılmaz, K. Köse, M.M. Sümer, M., Yurdusev, M.A. Use of Zeolite, Coal Bottom Ash and Fly Ash as Replacement Materials in Cement Production Cement and Concrete Research 34 2004: pp. 731-735.

17. Ahmadi, B., Shekarchi, M. Use of Natural Zeolite as a Supplementary Cementitious Material Cement \& Concrete Composites 32 2010: pp. 134-141.

18. Demir, A., Topcu, İ.B., Kuşan, H. Modeling of Some Properties of the Crushed Tile Concretes Exposed to Elevated Temperatures Construction and Building Materials 25 2011: pp. 1883-1889.

19. Peng, G.F., Huang, Z.S. Change in Microstructure of Hardened Cement Paste Subjected to Elevated Temperatures Construction and Building Materials 22 2008: pp. 593-599.

20. Odelson, J.B., Kerr, E.A. Vichit-Vadakan, W. Young's Modulus of Cement Paste at Elevated Temperatures Cement and Concrete Research 37 2007: pp. 258-263.

21. Gencel, O. Effect of Elevated Temperatures on Mechanical Properties of High-Strength Concrete Containing Varying Proportions of Hematite Fire and Materials 36 2012: pp. 217-230.

22. Siddique, R., Kaur, D. Properties of Concrete Containing Ground Granulated Blast Furnace Slag (GGBFS) at Elevated Temperatures Journal of Advanced Research 3 2012: pp. $45-51$. 